Вісник Харківського національного університету імені В.Н. Каразіна Серія "Математика, прикладна математика і механіка" Том 92,2020 , с. $44-56$

УДК УДК 532.5, 517.956.35
Visnyk of V.N.Karazin Kharkiv National University Ser. "Mathematics, Applied Mathematics and Mechanics"

Vol. 92, 2020, p. 44-56

DOI: $10.26565 / 2221-5646-2020-92-04$

\title{
A study of a quasilinear model of the particles of a suspension that are aggregated and settled in an inhomogeneous field
}

\author{
N. N. Kizilova ${ }^{1}$, S. A. Poslavskyi ${ }^{1}$, V. A. Baranets ${ }^{1}$ \\ ${ }^{1}$ V. N. Karazin Kharkiv National University \\ Svobody sqr., 4, 61022, Kharkiv, Ukraine \\ s.poslavsky@gmail.com,n.kizilova@gmail.com, cherevko.vita@gmail.com
}

A quasilinear system of three differential equations of hyperbolic type, which describes the settling of aggregating particles of a suspension placed in a thin long tube in a field of external forces inhomogeneous along the tube, is studied. The system of equations for mass and volume concentrations and the average size of aggregates in a one-dimensional formulation allows discontinuous solutions. The characteristics of the system correspond to the surfaces of discontinuities, of which the outer one describes the subsidence rate, and the inner one can have a different structure from a simple concentration jump to a jump accompanied by a rarefaction wave and a fan of characteristics at the moving boundary. A detailed study of the conditions for the existence of different types of solutions is carried out. The application of the results for different applied problems is discussed.

Key words: differential equations; hyperbolic systems; characteristics; sedimentation; aggregation.

Кізілова Н. М., Пославський С. О., Баранець В. О. Дослідження квазілінійної моделі осідання частинок суспензії, що агрегують, в неоднорідному полі сил. Досліджується квазілінійна система трьох диференціальних рівнянь гіперболічного типу, яка описує осідання частинок суспензії, що агрегують. Суспензія поміщена в тонку довгу трубку в неоднорідному уздовж трубки полі зовнішніх сил. Система рівнянь для масових і об'ємних концентрацій і середнього розміру агрегатів в одномірної постановці допускає розривні розв'язки. Характеристики системи відповідають поверхням розривів концентрацій агрегатів, з яких зовнішня поверхня визначає швидкість осідання, яка може вимірюватися в експериментах, а внутрішня може мати різну структуру від простого стрибка концентрацій до стрибка, який супроводжується хвилею розрідження або віялом характеристик на рухомий нижній границі. Проведено детальне дослідження умов існування різних типів розв'язків. Обговорюється застосування результатів для розв'язання різних прикладних задач.

Ключові слова: гіперболічні системи; характеристики; седиментація; агрегація.

(c) N. N. Kizilova, S. A. Poslavskyi, V. A. Baranets, 2020 
Кизилова Н. Н., Пославский С. А., Баранец В. А. Исследование квазилинейной модели оседания агрегирующих частиц суспензии в неоднородном поле сил. Исследуется квазилинейная система трех дифференциальных уравнений гиперболического типа, которая описывает оседание агрегирующих частиц суспензии, помещенной в тонкую длинную трубку в неоднородном вдоль трубки поле внешних сил. Система уравнений для массовых и объемных концентраций и среднего размера агрегатов в одномерной постановке допускает разрывные решения. Характеристики системы соответствуют поверхностям разрывов концентраций агрегатов, из которых внешняя поверхность определяет измеряемую в экспериментах скорость оседания, а внутренняя может иметь разную структуру от простого скачка концентраций до скачка, сопровождающегося волной разрежения или веером характеристик на подвижной нижней границе. Проведено детальное исследование условий существования разных типов решений. Обсуждается применение полученных результатов для решения различных прикладных задач.

Ключевые слова: гиперболические системы; характеристики; седиментация; агрегация.

2010 Mathematics Subject Classification: 35L57, 76T20

\section{Introduction}

As is known, in contrast to solutions of systems of linear differential equations, quasilinear equations of hyperbolic type

$$
\frac{\partial u_{i}}{\partial t}+\sum_{j=1}^{n} A_{i j} \frac{\partial u_{j}}{\partial x}=B_{i}, \quad i=1, \ldots, n,
$$

where $A_{i j}\left(t, x, u_{1}, \ldots, u_{n}\right)$ and $B_{i}\left(t, x, u_{1}, \ldots, u_{n}\right)$ is the matrix of coefficients and the vector of the right-hand sides of the system, and the equation $\operatorname{det}\left|A_{i j}-\lambda I_{i j}\right|=0$, where $I_{i j}$ is the unit matrix, has different real roots (characteristic values), with smooth initial data admit discontinuous solutions [1]. Such systems of equations describe wave propagation in multiphase [2] and non-Newtonian fluids [3], filtration in porous media with suffusion [4], kinematic waves in channels and cavities [5], as well as sedimentation of particles in polydisperse suspensions $[6,7,8]$. Investigations of sedimentation models for particles of dilute suspensions go back to the works of Batchelor [9, 10]. For concentrated suspensions, it was shown that in the one-dimensional case the system of equations describing the distribution of concentrations and volumes of settling aggregating (coagulating) particles [6,7], as well as particles of a polydisperse suspension [8] remains hyperbolic if the Stokes drag coefficient depends on the size and shape of the aggregate, when settling in a field of inhomogeneous force, and with a number of other complications of the original one-dimensional model. Studies of the solvability of problems in the theory of coagulation are of great interest for the theory of differential equations [11], as well as for modern nanosciences, bio and nanotechnologies [12]. 
In most works, instantaneous stratification of settling particles into a compressible sediment layer (zone III) at the bottom of the sedimentation tube, a zone of settling particles (hindered settling layer, zone II) above it, and an area of a stationary carrier fluid in the upper part of the tube (clear layer, zone I) for both technical [13] and biological [14] suspensions. In this case, the formulation of problem (1) in these cases includes the balance equations for the mass of particles with a mass concentration $C$ and a carrier liquid with concentrations $1-C$ in the form $[8,13,14]$

$$
\frac{\partial C}{\partial t}+\frac{\partial C u^{1}}{\partial x}=0, \quad \frac{\partial(1-C)}{\partial t}+\frac{\partial(1-C) u^{2}}{\partial x}=0,
$$

where $u^{1}$ and $u^{2}$ are velocities of the particles and fluid.

The sum of equations (2) with flow impermeability through the bottom of the tube gives the relation

$$
u^{1}=-(1-C) u_{s}
$$

where $u_{s}=u^{1}-u^{2}$ is the fluid velocity relatively to the aggregate [15].

The velocities $u^{1}$ and $u^{2}$ can be found from the momentum equations of particles and liquid [14], discrete equations of particle dynamics [16], or by introducing approximations for the coefficient $u_{s}(C)$ accounting for the difficulty of flow around settling particles in the zone II. Taking into account the known power-law approximation for the viscosity of the concentrated suspension [17]

$$
\mu_{e f f}=\mu_{0}(1-C)^{1-n},
$$

where $\mu_{0}$ is the viscosity of the basic fluid, $n$ is the empirical coefficient, it was accepted for $u_{s}(C)[15]$

$$
u_{s}(C)= \begin{cases}-u_{s 0}(1-C)^{n}, & C \leq C^{*} \\ 0, & C>C^{*}\end{cases}
$$

where $u_{s 0}=2\left(\rho_{s}-\rho_{f}\right) g R^{2} / 9 \mu_{0}$ is the sedimentation rate of spherical particles of radius $R$ in the basic fluid, $\rho_{s}, \rho_{f}$ are the densities of the particles and liquid, respectively, $g$ is the gravitational acceleration, $C^{*}$ is the critical concentration at which the particles form a quasi-solid viscoelastic framework and cannot settle $\left(u_{s}=0\right.$, and zone II transforms into zone III); i.e. at the boundary between zones II and III, the condition $C=C^{*}$ is satisfied, and it is often assumed for simplicity that $C^{*}=1$, so that in zone III there is also no movement of the basic fluid [15].

In this simple case, both characteristics are discontinuity lines of particle concentrations [18]

$$
\frac{d C}{d T}=0 \quad \text { along } \quad \frac{d Z}{d T}=\gamma(C)=\frac{\partial F}{\partial C},
$$

where $\gamma(C)$ is the characteristic equation, $F=C v^{1}(C)$ is the mass flow of the particles, $Z=z / L$ and $T=L u_{s 0} / h$ are dimensionless longitudinal coordinate and 
time, $L$ is the height of the sedimentation tube, and the speed of the discontinuity line (Rankine-Hugoniot condition) is

$$
c=\frac{F\left(C^{+}\right)-F\left(C^{-}\right)}{C^{+}-C^{-}},
$$

where $C^{+}, C^{-}$are the particle concentrations above and below the discontinuity line.

The first characteristic separates zones I and II; it has a negative slope $(z=0$ and $z=1$ correspond to the bottom and top of the tube, respectively) and determines the sedimentation rate measured in experiments $[2,3,5,6,8,14]$. The second characteristic is usually called internal [18]; it has a positive slope and can correspond (Fig. 1) either to a jump to maximum packing with the disappearance of zone II and the subsequent cessation of movement in zones I and III ( $C^{-}=C^{*}$, case 1 ), or a jump $C^{-} \neq C^{*}$ with a subsequent rarefaction wave up to $C^{-}=C^{*}$ (case 2) or a jump with a fan of rarefaction waves (rarefaction fan, case 3 ). The upper of the characteristics always has the highest speed $c(7)$, otherwise there will be an intersection of the number of constitutive relations and conditions for the evolutionary character of the discontinuity [1]. As a result, different types of sedimentation curves are obtained (upper dashed lines in Fig. 1a-d).

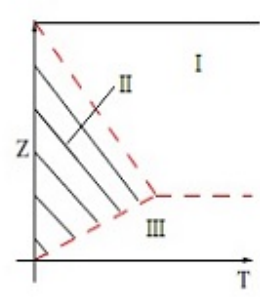

a

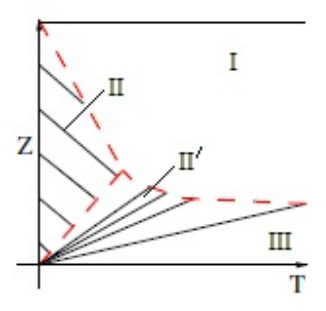

$\mathrm{b}$

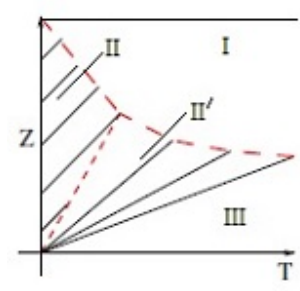

C

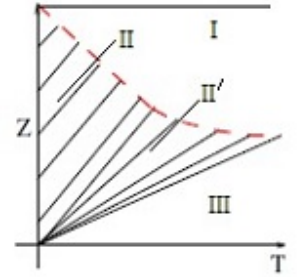

d

Fig. 1. Different options for internal concentration jump: case 1 (a), case 2 (b, c), case 3 (d) (adapted from [18])

Similar versions of families of characteristics were obtained for a bidisperse suspension [17]. As shown in a recently published article [16], discrete equations of particle dynamics, taking into account all possible forces of interactions between them, after averaging, give the Navier-Stokes equations of a two-phase suspension. Similar calculations on discrete models of a suspension of settling aggregating particles [19] showed good agreement with continual models [6, 8, 14].

In more complex cases, when the particles of the suspension during aggregation can capture a part of the basic fluid, which is then gradually percolate through the porous surface of the aggregate as it settles, the problem is reduced to a hyperbolic system of three differential equations for the mass $C$ and volume $H$ 
concentrations and the average volume $w$ of the aggregates (Fig. 2a). Many biological microparticles exhibit similar properties, for example, blood erythrocytes (Fig. 2b), polymers, nanoparticles [3, 5], etc.

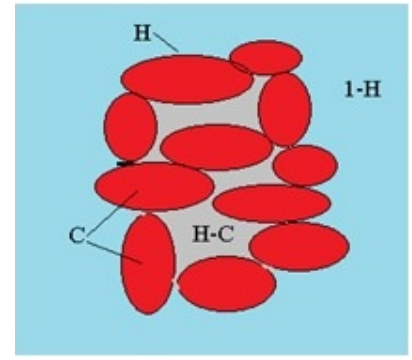

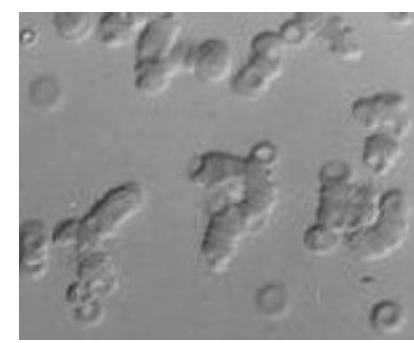

$\mathrm{b}$

Fig. 2. Structure of the aggregates in a three-phase liquid (a) and in human blood (b).

In this case, in the hyperbolic systems of the form (1), (2) for the variables $\{C, H, w\}$, a third family of characteristics appear, the slope of which can be either positive or negative, depending on the parameters of the model [8]. For the case of the aggregating particles in inclined tubes in an inhomogeneous external field, it was shown that other variants of the arrangement of families of characteristics can be added to the possible patterns of characteristics (Figs. 1a-d), which is also confirmed by numerical calculations based on the initial hyperbolic system of the continuum model $[8,20]$ by the finite volume method [21]. Since the settling of the particles in inclined tubes at certain angles of inclination leads to a significant acceleration of settling and separation of mixtures (Boycotte effect) and is widely used in oil and gas industry [22], biological [14, 23, 24] and nanotechnology $[3,5]$, the study of such sort of problems is of interest not only for the theory of hyperbolic differential equations, but also for many applied problems. Particle sedimentation in the inhomogeneous field of centrifugal forces makes it possible to accelerate the sedimentation process with the formation of sediments of different variable density, which can be used for additional medical diagnostics in biomedical applications or for the manufacturing of various nanostructured samples of particle-based materials in nanotechnology.

In this paper, a detailed analysis of the mathematical formulation of the sedimentation for a three-phase suspension of aggregating particles [8] in an inhomogeneous field is carried out. The difference of the studied model with similar already known formulations is that the hyperbolic system of differential equations is solved in the region (zone II), which has variable boundaries (characteristics of the 1 st and 2nd families), moving at the speeds $c_{1}, c_{2}$, respectively.

\section{Description of the mathematical model}

The model of the three-phase suspension composed of a free fluid (phase 1), particles (phase 2) and fluid captured inside the aggregates (phase 3) is considered. 
The main system of equations has a form [8]:

$$
\begin{gathered}
\frac{\partial w}{\partial t}+u^{2} \frac{\partial w}{\partial x}=\varphi \frac{w^{2}}{C}, \\
\frac{\partial H}{\partial t}+\gamma_{11} \frac{\partial H}{\partial x}+\gamma_{12} \frac{\partial C}{\partial x}+\gamma_{13} \frac{\partial w}{\partial x}=\theta+(1-H) \frac{\partial u^{1}}{\partial x}, \\
\frac{\partial C}{\partial t}+\gamma_{21} \frac{\partial H}{\partial x}+\gamma_{22} \frac{\partial C}{\partial x}+\gamma_{23} \frac{\partial w}{\partial x}=-C \frac{\partial u^{2}}{\partial x}, \\
\gamma_{11}=u^{1}-(1-H) \frac{\partial u^{1}}{\partial H}, \quad \gamma_{12}=-(1-H) \frac{\partial u^{1}}{\partial C}, \quad \gamma_{13}=-(1-H) \frac{\partial u^{1}}{\partial w}, \\
\gamma_{21}=C \frac{\partial u^{2}}{\partial H}, \quad \gamma_{22}=u^{2}+C \frac{\partial u^{2}}{\partial C}, \quad \gamma_{23}=C \frac{\partial u^{2}}{\partial w},
\end{gathered}
$$

where $C$ and $H$ are mass and volumetric concentrations of aggregates, $w$ is an average volume of aggregate, $\varphi$ is the aggregation rate, $u^{1}, u^{2}$, are the phase velocities, $\theta=\theta^{3} / \rho_{f}, \theta^{3}$ is the rate of the fluid capture during the aggregation.

In the matrix form the system (8)-(9) is:

$$
\frac{\partial}{\partial t}\left(\begin{array}{c}
w \\
H \\
C
\end{array}\right)+\left(\begin{array}{ccc}
u^{2} & 0 & 0 \\
\gamma_{13} & \gamma_{11} & \gamma_{12} \\
\gamma_{23} & \gamma_{21} & \gamma_{22}
\end{array}\right) \frac{\partial}{\partial x}\left(\begin{array}{c}
w \\
H \\
C
\end{array}\right)=\left(\begin{array}{c}
\frac{\varphi w^{2}}{C} \\
\theta+(1-H) k_{1} \\
-C k_{2}
\end{array}\right),
$$

where $k_{1}=\frac{\partial u^{1}}{\partial x}, k_{2}=\frac{\partial u^{2}}{\partial x}$.

The phase velocities are expressed explicitly through the variables $x, w, H, C$ :

$$
\begin{aligned}
& u^{1}=\left[-\frac{H(1-H)}{F}+\frac{(H-C)^{2}}{D}\right] C\left(\rho_{s}-\rho_{f}\right) 4 \pi^{2} \nu^{2}(x+a), \\
& u^{2}=\left[\frac{(1-H)^{2}}{F}+\frac{(H-C)^{2}}{D}\right] C\left(\rho_{s}-\rho_{f}\right) 4 \pi^{2} \nu^{2}(x+a), \\
& u^{3}=\left[\frac{(1-H)^{2}}{F}+\frac{(H-C)(1-H+C)}{D}\right] C\left(\rho_{s}-\rho_{f}\right) 4 \pi^{2} \nu^{2}(x+a),
\end{aligned}
$$

where $\rho_{s}, \rho_{f}$ are physical densities of particles and free fluid, $\nu$ is a centrifuge rotation frequency, $a$ is a distance from a disc center to tubes.

Thermodynamic coefficients $F, D$ are [6]:

$$
\begin{aligned}
& F=\alpha \eta_{f} H(1-H)^{-\eta_{1}}\left(\frac{H}{C}\right)^{2 / 3} w^{-2 / 3}, \\
& D=\beta \eta_{f} C\left(1-\frac{C}{H}\right)^{-\eta_{2}} w_{0}^{-2 / 3},
\end{aligned}
$$


where $\alpha, \beta, \eta_{1}, \eta_{2}$ are positive constants, $w_{0}$ is a volume of one particle, $\eta_{f}$ is a fluid viscosity.

This system is hyperbolic with characteristic values of the defining parameters. Therefore, for its analysis and solution the method of characteristics is effective. The characteristic values $\lambda_{1}, \lambda_{2}, \lambda_{3}$ are:

$$
\begin{aligned}
& \lambda_{1}=u^{2} \\
& \lambda_{2,3}=\frac{\left(\gamma_{11}+\gamma_{22}\right) \pm \sqrt{\left(\gamma_{11}-\gamma_{22}\right)^{2}+4 \gamma_{12} \gamma_{21}}}{2}
\end{aligned}
$$

The families of characteristics and corresponding conditions at them are:

$$
\begin{aligned}
& \left(\frac{d x}{d t}\right)_{1}=u_{s}+u_{f} \\
& \left(\frac{d x}{d t}\right)_{2,3}=u_{s}+u_{f}+\frac{1}{2} A\left(1 \pm \sqrt{1-B / A^{2}}\right) \\
& \left(\frac{d w}{d t}\right)_{1}=\varphi \frac{w^{2}}{C}, \\
& \frac{1}{2}\left[A_{1}\left(1 \pm \sqrt{1-B / A^{2}}\right)-A_{2}\left(1 \mp \sqrt{1-B / A^{2}}\right)\right] \times \\
& \times\left(\left(\frac{d H}{d t}\right)_{2,3}-\theta-(1-H) k_{1}\right)+\gamma_{12}\left(C k_{2}+\left(\frac{d C}{d t}\right)_{2,3}\right)=0
\end{aligned}
$$

where

$$
\begin{gathered}
u_{s}=\frac{(1-H)^{2} C\left(\rho_{s}-\rho_{f}\right) 4 \pi^{2} \nu^{2}(x+a)}{F}, u_{f}=\frac{(H-C)^{2} C\left(\rho_{s}-\rho_{f}\right) 4 \pi^{2} \nu^{2}(x+a)}{D}, \\
A_{1}=H \frac{\partial u_{s}}{\partial H}-(1-H) \frac{\partial u_{f}}{\partial H}, \quad A_{2}=C \frac{\partial u_{s}}{\partial C}+\frac{\partial u_{f}}{\partial C}, \quad A=A_{1}+A_{2}, \\
B=4 C\left(\frac{\partial u_{s}}{\partial H} \cdot \frac{\partial u_{f}}{\partial C}-\frac{\partial u_{s}}{\partial C} \cdot \frac{\partial u_{f}}{\partial H}\right) .
\end{gathered}
$$

The equations of the first family of characteristics coincide with the equations for the trajectories of solid phase particles (similar to contact characteristics in gas dynamics). Therefore, the boundary separating the area of settling particles from the area occupied by a stationary fluid moves at the speed $u^{2}$ of those particles (aggregates) that are on it. In this case, the effective densities and velocities of the phases at this boundary are discontinuous. There is no need to set special jump conditions here, because in the area occupied by the suspension, all parameters are determined by integrating the characteristic equations (by the method of characteristics). 
The situation is quite different with the setting of boundary conditions at the boundary of the compact zone. Depending on the relationship between the characteristic speeds and the speed of this boundary, different regimes can be realized.

If this boundary is a strong discontinuity, then corresponding conditions for the limit values must be performed on it when approaching the jump from one side and from the other:

$$
\begin{aligned}
& w_{I I}=w_{I I I}, \quad\left(1-H_{I I I}\right) Z_{I I-I I I}=\left(1-H_{I I}\right)\left(Z_{I I-I I I}-u_{I I}^{1}\right), \\
& Z_{I I-I I I} C_{I I I}=\left(Z_{I I-I I I}-u_{I I}^{2}\right) C_{I I},
\end{aligned}
$$

where $Z_{I I-I I I}$ is a velocity of the discontinuity.

\section{Analysis of possible cases}

According to the general theory of discontinuous (or generalized, or weak) solutions of systems of quasilinear equations [25, 26], existence of an evolutionary (not decaying into a system of waves) discontinuity is ensured by the following condition. The number of characteristic lines arriving to the same point at the discontinuity surface should be such that, in the problem of small perturbations, the perturbations of all the quantities are uniquely determined from the conditions along these characteristics and the constitutive relations at the discontinuity. For example, if the same hyperbolic system of $n$ quasilinear equations is satisfied in regions on both sides of the discontinuity, then the number of arriving characteristics from one side and from the opposite should be exactly $n+1$. Indeed, in this case, the number of unknowns is equal to $2 n+1$ ( $n$ unknown functions on each side of the discontinuity and an unknown speed of it), which means that there should be the same number of equations for their determination. If, however, some additional conditions are fulfilled at the jump, then the number of characteristic lines arriving to the jump should be reduced by the number of conditions.

In the problem under consideration, the situation is somewhat different. The main system of equations (8)-(9) is satisfied only on one side of the discontinuity, and on the other, the state of all phases is considered to be specified (we mean the packing density of aggregates and the volumetric content of fluid in the compact zone, i.e., the values of $H_{I I I}$ and $\left.C_{I I I}\right)$ ). Only the quantity $w_{I I I}$ remains unknown in the compact zone, but it satisfies the condition $w_{I I I}=w_{I I}$.

Therefore, for the stability of the discontinuity, it is necessary that the characteristics of two families enter the jump, and only the characteristics of one family are outgoing (Fig. 3). Accordingly, the characteristic velocities and the discontinuity velocity $Z_{I I-I I I}$ must satisfy the following inequalities:

$$
\left(Z_{I I-I I I}-\left(\frac{d x}{d t}\right)_{2}\right) \cdot\left(Z_{I I-I I I}-\left(\frac{d x}{d t}\right)_{3}\right)<0 .
$$




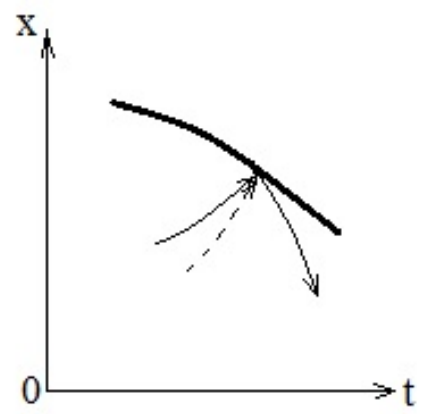

Fig.3. Location of characteristics relative to the strong discontinuity line.

If this condition is not satisfied, then there is no strong discontinuity on the boundary of the compact zone, since it does not satisfy the evolutionary condition and cannot be stable.

But then the structure of the solution should be different. Instead of a strong discontinuity, the transition from zone $I I$ to zone $I I I$ should be carried out in a more complicated manner. Apparently, in this case, the mathematical model of the studied process of particle sedimentation needs to be revised. At a sufficiently high concentration of aggregates, the relationship between the phase velocities and concentrations described by relations (11) is no longer sufficiently adequate.

\section{Conclusions}

In this paper, we consider the properties of solutions of a quasilinear hyperbolic system of partial differential equations describing the process of settling and aggregation of particles under conditions of an inhomogeneous field of external forces. We study the conditions for the existence of different types of solutions. The results obtained make it possible to analyze various modes and the influence of model parameters on the sedimentation process. The estimation of the number of incoming and outgoing characteristics for the strong discontinuity between the zone of settling aggregates and the compact zone is carried out. The obtained condition determines the existence and stability of this discontinuity. If it is not satisfied, the mathematical model describing the process of settling and aggregation of suspension particles requires correction. The results obtained can be used to solve various applied problems, in particular, in the field of medicine.

\section{ORCID ID}

N. N. Kizilova (iD https://orcid.org/0000-0001-9981-7616

S. A. Poslavskyi (iD) https://orcid.org/0000-0002-1049-9947

V. A. Baranets (iD https://orcid.org/0000-0001-6386-3207 


\section{REFERENCES}

1. B. L. Rozhdestvensky. Discontinuous solutions of quasilinear equations systems of hyperbolic type, Uspekhi of Mathematical Sciences, - 1960. V. 15, 6(96). - P. 59-117.

2. S.-J. Lee, K.-S. Chang, K. Kim. Pressure wave speeds from the characteristics of two fluids, two-phase hyperbolic equation system, International Journal of Multiphase Flow, - 1998. - Vol. 24. - P. 855-866. doi:10.1016/S03019322(97)00089-X

3. A. Farina, L. Fusi, A. Mikelić, G. Saccomandi, et al. Non-Newtonian Fluid Mechanics and Complex Flows. 2018. Springer, Cham, 330 p. https://doi.org/10.1007/978-3-319-74796-5

4. A. Yu. Kuznetsov, S. A. Poslavskyi. Investigation of a mathematical model of the mechanical suffusion, Visnyk of V.N. Karazin Kharkiv National University. Ser. Mathematics, Applied Mathematics and Mechanics, - 2009. - № 875. - P. 57-68 (in Russian). http://vestnik-math.univer.kharkov.ua/VestnikKhNU-875-2009-kuznietsov.pdf

5. V. P. Singh. Kinematic wave modeling in water resources: Surface-water hydrology. 1996. Wiley, New York, 1424 p.

6. E. S. Losev. Modelling of the aggregating particles sedimentation, Izvestiya of AN SSSR, Ser. MZhG, - 1983. - № 3. - P. 71-78.

7. D. K. Basson, S. Berres, R. Bürger. On models of polydisperse sedimentation with particle-size-specific hindered-settling factors, Applied Mathematical Modelling, - 2009. - Vol. 33. - P. 1815-1835. doi:10.1016/j.apm.2008.03.021

8. V. Baranets, N. Kizilova. Mathematical modeling of particle aggregation and sedimentation in the inclined tubes, Visnyk of V.N.Karazin Kharkiv National University. Ser. Mathematics, Applied Mathematics and Mechanics, - 2019. - Vol. 90. - P. 42-59. doi:10.26565/2221-5646-2019-90-03

9. G. K. Batchelor. Sedimentation in a dilute polydisperse system of interacting spheres, Part 1. General theory, Journal of Fluid Mechanics, - 1982. Vol. 119. - P. 379-408. doi:10.1017/S0022112082001402

10. G. K. Batchelor, C.S. Wen. Sedimentation in a dilute polydisperse system of interacting spheres, Part 2. Numerical results, Journal of Fluid Mechanics, 1982. - Vol. 124. - P. 495-528. doi:10.1017/S0022112082002602

11. F. P. da Costa, R. Sasportes, Dynamics of a Non-Autonomous ODE System Occurring in Coagulation Theory, Journal of Dynamics and Differential Equations, - 2008. - Vol. 20. - P. 55-85. doi:10.1007/s10884-006-9067-5 
12. E. M. Hotze, T. Phenrat, G. V. Lowry. Nanoparticle Aggregation: Challenges to Understanding Transport and Reactivity in the Environment, Journal of Environmental Quality, - 2010. - Vol. 39. - P. 1909-1924. doi:10.2134/jeq2009.0462

13. R. Bürger. Phenomenological foundation and mathematical theory of sedimentation-consolidation processes, Chemical Engineering Journal, - 2000. Vol. 80. - P. 177-188. doi:10.1016/S1383-5866(00)00089-7

14. V. A. Levtov, S. A. Regirer, N. Kh. Shadrina. Rheology of blood. 1982. Medicine, M., 270 p.

15. R. Dorrell, A. J. Hogg. Sedimentation of bidisperse suspensions, International Journal of Multiphase Flow, - 2010. - Vol. 36. - P. 481-490. doi:10.1016/j.ijmultiphaseflow.2010.02.001

16. J. Zhang, W. Ma. Data-driven discovery of governing equations for fluid dynamics based on molecular simulation, J. Fluid Mech., - 2020. - Vol. 892, A5. - P. 1-15. doi:10.1017/jfm.2020.184

17. J. F. Richardson, W. N. Zaki. The sedimentation of a suspension of uniform spheres under conditions of viscous flow, Chemical Engineering, - 1954. Vol. 3. - P. 65-78. doi:10.1016/0009-2509(54)85015-9

18. G. J. Kynch. A theory of sedimentation, Transactions of Faraday Society, 1952. - Vol. 48. - P. 166-176. doi:10.1039/TF9524800166

19. V. A. Baranets, N. N. Kizilova. The discrete simulation and sedimentation of micro- and nanoparticles in suspensions, Ser. Mathematical Modelling. Information Technology. Automated Control Systems, - 2018. - V. 40. - P. 414 (in Russian). doi:10.26565/2304-6201-2018-40-01

20. V. Baranets, N. Kizilova. On hyperbolicity and solution properties of the continual models of micro/nanoparticle aggregation and sedimentation in concentrated suspensions, Bulletin of Taras Shevchenko National University of Kyiv. Ser. Physics \& Mathematics, - 2019. - N. 4, - P. 60-64. https://doi.org/10.17721/1812-5409.2019/4.7

21. R. Ruiz-Baiera, H. Torres. Numerical solution of a multidimensional sedimentation problem using finite volume-element methods, Applied Numerical Mathematics, - 2015, V. 95, - P. 280-291. doi:10.1016/j.apnum.2013.12.006

22. T. Peacock, F. Blanchette, J. W. M. Bush. The stratified Boycott effect, Journal of Fluid Mechanics, - 2005. - V. 529. - P. 33-49. doi:10.1017/S002211200500337X

23. L. Derbel. The set of concentration for some hyperbolic models of chemotaxis, Journal of Hyperbolic Differential Equations, - 2007. - V. 4, N. 2. - P. 331349. doi:10.1142/S021989160700115X 
24. H. Yan, W.-A. Yong. Stability of steady solutions to reaction-hyperbolic systems for axonal transport, Journal of Hyperbolic Differential Equations, 2012. - Vol. 9, N. 2. - P. 325-37. doi:10.1142/S0219891612500105

25. I. M. Gelfand. Some problems of the quasilinear equations theory, UMN, 1959. - V. 14, 2 (86). - P. 87-158.

26. G. G. Cherniy. Gas dynamics. 1988. Nauka, M., 424 p.

\author{
Дослідження квазілінійної моделі осідання частинок суспензії, \\ які агрегують, в неоднорідному полі сил \\ Кізілова, Н. М., Пославський, С. О., Баранець, В. О. \\ Харківсъкий національний університет ім. В. Н. Каразіна \\ пл. Свободи, 4, Харків, Украӥна, 61022
}

Математична модель процесу осідання частинок суспензії зазвичай являє собою квазілінійну гіперболічного систему диференціальних рівнянь, доповнену початковими і крайовими умовами. В даній статті досліджується ускладнена модель, що враховує агрегування частинок і неоднорідність поля зовнішніх масових сил. Розглянуто випадок однорідних початкових умов, коли всі параметри руху, що виникає, залежать тільки від однієї просторової декартової координати $x$ і від часу $t$. На відміну від відомих постановок задач для квазілінійних систем рівнянь (наприклад, в газовій динаміці), розв'язки яких містять сильні розриви, у досліджуваній постановці основна система рівнянь виконується тільки по один бік від лінії розриву в площині змінних $(t ; x)$. По інший бік від лінії розриву рівняння, взагалі кажучи, мають принципово інший вигляд. Ми обмежуємося вивченням випадку, коли в компактній зоні, зайнятій осілими частинками, ніякого руху немає, тобто усі швидкості дорівнюють нулю і об'ємні частки всіх фаз не змінюються з часом. Розглянуто задачу про седиментацію еритроцитів в полі відцентрових сил в центрифузі, при їі рівномірному обертанні з кутовою швидкістю $\omega=$ const. Проведено дослідження умов існування різних типів розв'язків. Однією з основних є проблема еволюційності (стійкості) виникаючих сильних розривів. Розв'язання цієї проблеми пов'язано з аналізом співвідношень для характеристичних швидкостей і швидкості переміщення поверхні розриву. Відповідь залежить від числа характеристик, що приходять до розриву, і від кількості додаткових умов, що задаються на поверхні розділу. Розрив на нижній межі області, зайнятої чистої плазмою, завжди стійкий. Але для поверхні розриву, що розділяє зони осілих і рухомих частинок, умова еволюційності може порушуватися. В цьому випадку необхідне коригування вихідної математичної моделі. Ключові слова: гіперболічні системи; характеристики; седиментація; агрегація.

\title{
A study of a quasilinear model of the particles of a suspension that are aggregated and settled in an inhomogeneous field \\ N. N. Kizilova, S. A. Poslavskyi, V. A. Baranets \\ V. N. Karazin Kharkiv National University, 4 Svobody sqr., Kharkiv, 61022, Ukraine
}

The mathematical model of the sedimentation process of suspension particles is usually a quasilinear hyperbolic system of partial differential equations, supplemented by initial and boundary conditions. In this work, we study a complex model that takes into account the aggregation of particles and the inhomogeneity of the field of external mass forces. The case of homogeneous initial conditions is considered, when all the parameters of the arising motion depend on only one spatial Cartesian coordinate $x$ and on time $t$. In 
contrast to the known formulations for quasilinear systems of equations (for example, as in gas dynamics), the solutions of which contain discontinuities, in the studied formulation the basic system of equations occurs only on one side of the discontinuity line in the plane of variables $(t ; x)$. On the opposite side of the discontinuity surface, the equations have a different form in general. We will restrict ourselves to considering the case when there is no motion in a compact zone occupied by settled particles, i.e. all velocities are equal to zero and the volumetric contents of all phases do not change over time. The problem of erythrocyte sedimentation in the field of centrifugal forces in a centrifuge, with its uniform rotation with angular velocity $\omega=$ const is considered. We have studied the conditions for the existence of various types of solutions. One of the main problems is the evolution (stability) problem of the emerging discontinuities. The solution of this problem is related to the analysis of the relationships for the characteristic velocities and the velocity of the discontinuity surface. The answer depends on the number of characteristics that come to the jump, and the number of additional conditions set on the interface. The discontinuity at the lower boundary of the area occupied by pure plasma is always stable. But for the surface separating the zones of settled and of moving particles, the condition of evolution may be violated. In this case, it is necessary to adjust the original mathematical model.

Keywords: hyperbolic systems; characteristics; sedimentation; aggregation.

Article history: Received: 5 October 2020; Final form: 10 November 2020;

Accepted: 15 November 2020. 